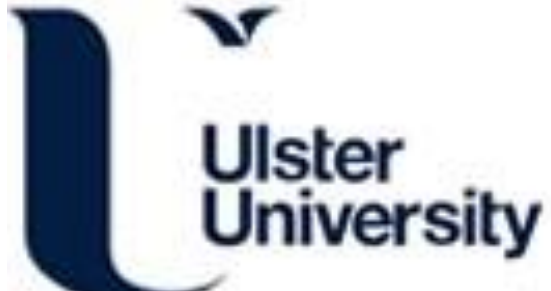

\section{Teaching Across the Divide: perceived barriers to the movement of teachers across the traditional sectors in Northern Ireland}

Milliken, M., Bates, J., \& Smith, A. (2020). Teaching Across the Divide: perceived barriers to the movement of teachers across the traditional sectors in Northern Ireland. British Journal of Educational Studies, 69(2), 133154. https://doi.org/10.1080/00071005.2020.1791796

Link to publication record in Ulster University Research Portal

Published in:

British Journal of Educational Studies

Publication Status:

Published online: 15/07/2020

DOI:

10.1080/00071005.2020.1791796

\section{Document Version}

Author Accepted version

\section{General rights}

Copyright for the publications made accessible via Ulster University's Research Portal is retained by the author(s) and / or other copyright owners and it is a condition of accessing these publications that users recognise and abide by the legal requirements associated with these rights.

\section{Take down policy}

The Research Portal is Ulster University's institutional repository that provides access to Ulster's research outputs. Every effort has been made to ensure that content in the Research Portal does not infringe any person's rights, or applicable UK laws. If you discover content in the Research Portal that you believe breaches copyright or violates any law, please contact pure-support@ulster.ac.uk. 


\title{
Teaching Across the Divide: perceived barriers to the movement of teachers across the traditional sectors in Northern Ireland
}

\author{
Matthew Milliken* (ORCiD: 0000-0002-6233-487X, Twitter: \\ @UlsterMilliken), Jessica Bates (ORCiD: 0000-0002-0854-2205, Twitter: \\ @Jessica_Bates) and Alan Smith (ORCiD: 0000-0003-3891-6543)
}

\author{
${ }^{a}$ School of Education, Ulster University, Coleraine, Northern Ireland \\ * Matthew Milliken, Ulster University, UNESCO Centre, School of Education, \\ Cromore Road, Coleraine, BT52 1SA m.milliken@ulster.ac.uk
}

Dr Matthew Milliken is employed as a researcher with the UNESCO Centre in the Ulster University's School of Education. He has extensive professional experience of managing and delivering cross community and good relations projects in Northern Ireland. He has also developed innovative educational approaches to support the addressing of inter-community tensions in Germany, Southern Africa and the Caucasus. His research interests lie in the policies, practices and perceptions that militate against the establishment of a common system of schooling in Northern Ireland. Matthew is currently engaged in the Transforming Education project which uses academic research to stimulate public discussion by illuminating issues that sustain the separation of schooling in Northern Ireland.

Dr Jessica Bates is a Senior Fellow of the Higher Education Academy and an experienced lecturer and researcher in the School of Education, Ulster University where she is Course Director for the Library and Information Management programme and undertakes research across Education and Library and Information Science. Dr Bates' research interests relate to information, education and social inclusion; digital literacy; and improving library and information services. She is currently leading a series of Community Conversations with local communities across Northern Ireland about education provision in their area and has developed a Community Conversation Toolkit for use in this work. She is also currently researching citizenship education and political literacy amongst young people in Northern Ireland.

Professor Alan Smith, Director of the UNESCO Centre in Ulster University, is a specialist in education and conflict with 25 years' experience including responsibility for the management and completion of more than thirty externally-funded research and development projects. His work 
includes research on education and the conflict in Northern Ireland, young people's understanding of human rights and the development of social, civic and political education. 


\section{Teaching Across the Divide: perceived barriers to the movement of teachers across the traditional sectors in Northern Ireland}

The community separation of the school system in Northern Ireland limits opportunities for daily cross-community interaction between young people. The deployment pattern of teachers is largely consistent with this divide. Pupils are therefore unlikely to be taught by a teacher from a community background other than their own. Nonetheless, recent research has shown that an increased proportion of teachers are diverting from the community consistent path and are teaching in a school not associated with their own community identity, although this remained a very uncommon choice. Narrative interviews with a purposive sample of these 'cross-over' teachers provide illustrations of the factors that preserve the separation of the teaching profession by community identity. Thematic analysis of this data reveals that policy, perceptions and practice combine to restrict the possibility of cross-community career movement by teachers. If the outworkings of community division in Northern Ireland are to be addressed, then these issues will need to be considered, and actions taken to mitigate this segregation.

Keywords: teacher identity, segregated education, community division, Northern Ireland

(Word Count: 6,955-excluding references) 


\section{Introduction}

It is half a century since the conflict known colloquially as 'the Troubles' began in Northern Ireland (NI), and two decades have passed since the signing of the Good Friday Agreement peace accord. However, deep societal, sectarian schisms remain evident. It has been proposed that the consociational Assembly introduced in the wake of the Agreement has allowed the two political blocs which represent the two dominant communities, Protestant-Unionist-Loyalist and Catholic-Nationalist-Republican, to 'share-out' rather than 'share' power (Barry, 2017). The NI education system provides a particularly stark illustration of the way in which services are divided-out rather than shared, although it is important to recognise that educational division in Northern Ireland has deep, historical roots.

Following the partition of Ireland in 1922, the Northern Ireland Ministry of Education had attempted to introduce a single non-denominational system to replace the existing array of church-run schools (Akenson, 1973). These secular aspirations were opposed by both the Protestant churches and the Catholic authorities (Farren, 1989). The NI Government ceded to these pressures and three classes of school emerged: (NI state) Controlled, (Catholic) Maintained, and Voluntary (grammar schools - both Catholic and non-denominational).

The 2019-20 school census identified that 93\% of pupils attended these three school types. Of the pupils attending schools under Catholic management 96\% were Catholic as opposed to $7 \%$ of those who attended Controlled schools (DE, 2020).

For the Irish/Catholic populace, Maintained schools and Catholic grammar schools historically provided a medium through which spirituality and morality could be 
embedded, whilst at the same time fostering community solidarity and Irish identity. In contrast, Controlled schools and non-denominational grammars in NI have promoted a syllabus, style and system of education that has a British orientation (Hughes, 2011); these schools also have a Christian foundation but place less direct focus on the denominational aspects of Protestant faith (Nelson, 2010).

In 1981, the first planned Integrated school was established in Northern Ireland. Despite commitments made in the 1998 Agreement to "facilitate and encourage integrated education", and opinion polls that regularly show that around $60 \%$ of parents support the principle of mixed schooling (Wyatt, 2019), figures provided by the NI Department of Education document that, since 1998, there has been only a small change in the proportions of children that are educated in Integrated schools (Figure 1). The community separation evident in the profiles of the pupils that attend schools in the Controlled and Maintained sectors remains a striking and pervasive feature of education (see Gallagher, 2019).

The Education and Libraries (Northern Ireland) Order 1986, Section 21 stipulates that all schools in NI must provide a daily act of collective worship and include Religious Education based upon the "Holy Scriptures" within the range of subjects that they provide for all pupils from Foundation to Key Stage 4. In this sense all schools in NI could be regarded as 'faith based' but the prominence afforded to religion within the various sectors differs. Controlled schools are non-denominational and "the balance is tilted firmly in favour of the secular over the religious" (Barnes, 2005; 129); Maintained schools on the other hand are "unapologetically confessional" (Armstrong, 2009; 298), they are seen as principally aiming to produce religious commitment to Catholicism. 
In spite of having been largely established in the absence of any official church representation, the character of Integrated schools is nevertheless, essentially Christian (Wardlow, 2013).

Since the late 1970s many policies have been introduced with the aim of encouraging the building of bridges between schools on either side of the divide. The most recent of these, Shared Education, foregrounds the improvement of pupils' educational outcomes with reconciliation as a complimentary dimension (Department of Education NI, 2015). The policy, which was endorsed by political parties on both sides, adopts the approach of accepting the apparent immutability of the structural divide and (at a time of fiscal austerity) provides considerable funding to encourage co-operation between schools, including shared learning activities.

The impact of the separation of pupils has attracted significant academic attention but the experiences of teachers have, in comparison, been relatively under-researched. Quantitative studies by Darby et al (1977) and the Equality Commission (2004) indicated that the community separation of schools was mirrored in the identity profile of the staff employed to teach within them (Table 1, Table 2). This was supported by a qualitative study (Dunn \& Gallagher, 2002) which suggested that teachers largely accepted this state of affairs and few considered employment options on the other side. Smith and Hansson (2015) proposed that the separation of teachers was also maintained by policy: the exception of teachers from protection under the 1998 NI Fair Employment and Treatment Order (FETO) and the occupational requirement for those seeking employment in Maintained primary schools to be in possession of a Certificate in Religious Education that has been endorsed by the Catholic Schools' Trustee Service. 
More recent research by Milliken et al (2020) has however indicated that the 'chill factor' identified by Dunn and Gallagher (2002) may have thawed slightly. Whilst community consistency in the deployment of teachers was still very evident in Maintained and Controlled primaries, the profile of post-primaries - and particularly grammar schools was more mixed than had been observed in earlier research. Teachers with a community identity other than that shared by the overwhelming majority of staff and students were present in all types of school (Table 3). No qualitative research has previously been conducted to explore the experiences of those teachers who had crossed this community divide or to identify what challenges they might face in making this transition.

Many teachers do not seek employment opportunities outside of their own community they will therefore neither encounter barriers nor deeply consider how, or why, taking such a path may prove difficult. By accessing the stories of those teachers that had taken an atypical career path this research project set out to cast a light on the obstacles that they encountered and thereby to identify the factors that they perceived as impacting upon on the movement of teachers across the traditional sectors in NI.

\section{Conceptual Framework}

The sociologist and philosopher Pierre Bourdieu proposed that social hierarchies are reproduced through the combination of the effects of cultural, social and economic capital. He identified educational settings as being particularly influential in this process in that they both assist in the formation of an individual's set of predispositions, habitus, and create the specific field within which that habitus is realised or deployed (Grenfell, 2014). A teacher's habitus is shaped by having passed through the field of education policy, systems, programmes and practices that are embedded within local, national and 
global political economies (Dale and Robertson, 2009). It follows that "teachers represent the most finished products of the system of production which it is, inter alia, their task to reproduce" (Bourdieu and Passeron, 1990; 197). However, as Mills (2008) points out, habitus does not need to be viewed solely as deterministic - it also has transformative potential. Ultimately "habitus shapes but does not determine our life choices" (Mills, $2008 ; 82$ ) and, as this research demonstrates, fields can be arenas of struggle and powerplay (Mills, 2008; 86).

Bourdieu was seeking to present an understanding of the processes affecting social exclusion, but, as has been shown, education in NI is characterised by two, similarly strong, almost mutually exclusive school systems that employ a workforce of teachers that is, for the most part, community consistent and reflective of the community divide that underpinned the NI conflict. Novelli et al (2015) examined the critical cultural political economy of education in conflict-affected regions throughout the world in order to develop a theoretical framework for analysing the potential contribution of education to sustainable peacebuilding. Their work proposed an understanding of peace as more than simply the absence of conflict. They drew attention to the importance of "teaching about the past and its relevance to the present and future" and "of how education contributes to integration and segregation" (Novelli et al, 2015; 16).

Whilst Shared Education programmes have undoubtedly created greater opportunities for contact between teachers in the divided schools in NI there is evidence that teachers may be unwilling to engage in contentious issues (McCully and Emerson, 2014; ETI, 2018). There is a risk that teachers may, in effect, be reproducing the cultural grammar of polite avoidance as described by Gallagher (2004) and McMaster (1993). 
This research set out to gain an understanding of how teachers perceive the manner in which the habitus and field of education in NI sustain the professional separation of teachers and thus the perpetuation of the divided system.

\section{Research Method}

Narrative inquiry has been identified as a methodology that is well suited to the exploring of under-researched social phenomena (Squire et al, 2014). Storytelling can be useful in uncovering the ways in which people make sense of their experiences and the environment in which they find themselves (Bates, 2004). Elbaz (1990) proposed that storytelling is a particularly apposite medium through which to conduct research with teachers; it is well-matched with their professional mindset and their capacity to communicate effectively. It is, however, necessary for researchers to be aware that the stories told in a narrative research setting can only be understood as a co-constructed ordering of events within a specific context and to a specific audience. They cannot be considered to be presentations of an objective 'truth'. This co-construction is a shared labour between the interviewee and the interviewer and will only ever be a version of reality (Squire et al, 2014).

One of the merits of narrative analysis is that it seeks to preserve the "wealth of detail" (Riessman, 2008; 74), however, in so doing, it has also been open to the criticism that it a method that unduly stresses the importance of the individual over the social context (e.g. Clandinin and Connelly, 2000). Since the focus of this research is to identify the factors that affect the intersection between a teacher's identity and their role in a specific social situation (i.e. a school), an adapted narrative analysis was applied. 
Polkinghorne (1995) illustrated how using a paradigmatic-type narrative inquiry (which gathers stories but uses paradigmatic analytic procedures to produce taxonomies and categories out of the common elements across all of the data) "allow[s] us to manage the uniqueness and diversity of each experience" within a "conceptually identified situation" (Polkinghorne,1995; 11). Habitus is a "complex amalgam of past and present" (Mills, $2008 ; 80$ ), therefore both diachronic data (accounts of the sequence of personal events in historical context) and synchronic data (information about the current situation) needed to be accommodated. The data was therefore collected using applied narrative techniques. Whilst some focus is needed on the ways in which the story has been told sequencing, specific language, pauses and emotion - the focus in this project is primarily on content and themes rather than a detailed discourse analysis.

Shukla et al (2014) identified methods of narrative inquiry and thematic analysis could be combined. Thematic analysis allows for the organisation and description of data in great detail. The analyst is required to visit and revist the material; coding, recoding, naming, renaming and relocating data as issues of research interest emerge. Braun and Clarke (2006) identified six steps within this recursive process and advocated that, through these cycles, data should be reviewed at two interpretative levels: Descriptive Analysis (a literal description of events) and Conceptual Analysis (reflection and the identification of deeper meaning). Ultimately, the aim of these processes is to develop clusters of meaning or 'Themes'. The rich description of the dataset that is facilitated through thematic analysis means that the method is well suited to narrative inquiry (Hajisoteriou, et al, 2015).

Interview Structure and Design 
An informal conversation is unlikely to draw out the necessary information in any consistent manner over a limited number of interviews, on the other hand, a heavily structured interview is likely to limit interviewees' ability to develop a flowing personal narrative. A semi-structured interview provides enough form to ensure continuity in the data presented by various participants yet enough flexibility to allow for interviewees to take tangents to illustrate life incidents that affected their career path and/or their personal perspective: critical events. Silverman (2013) proposed that, in order to conduct semistructured interviews, the interviewer requires a prepared set of questions - a schedulebut advised that these should only be used as a guide, that departures are to be encouraged rather than being seen as a problem. Questions were therefore designed to draw out critical events relating to personal and professional histories and to encourage reflection on the career paths that the interviewees had taken. They were sequenced to allow for a chronological flow of narrative.

This schedule was then tested through interviews with two volunteers - retired teachers who had been educated in a community consistent primary school in NI but who had taught extensively in a school with a community profile different from their own background. The interview schedule was revised in light of their comments and critical reflection on the style, sequencing and construction of the questions.

Each interview commenced with a series of questions relating to the interviewee's personal motivation and experience of education on their way to becoming a teacher before exploring the nature of their current post and their engagement with the culture of the school within which they were employed. The interview concluded with a series of 
questions about their perspective on their professional future and their reflections on what factors affected the community-consistent separation of teachers.

\section{Data Sufficiency}

Qualitative research has traditionally sought to achieve data saturation; when "no new properties, dimensions, conditions, actions/interactions, or consequences are seen in the data" (Strauss and Corbin, 1998, 136) - the point at which further data collection brings no new information. Saturation is however affected not just by the quantity of material; the quality of the data, the skill of the researcher, the ambition and scope of the enquiry and its design will also impact upon the stage at which saturation occurs (Charmaz, 2006; Ritchie et al, 2003; Morse, 2000). In order to facilitate planning, there is a pragmatic requirement to ensure that the task of data collection is manageable within the constraints of time and other limited resources.

Establishing data sufficiency within a narrative inquiry is particularly problematic given the thick, rich descriptions that can be provided by participants. The development of a Purposive Sample - "the deliberate choice of a participant due to the qualities the participant possesses" Etikan et al $(2016 ; 2)$ - is an accepted means of creating a practical solution to the challenge of ensuring data sufficiency. It is a non-random technique; the researchers decide what needs to be known and set out to find people who are able and willing to provide the information by virtue of their knowledge or experience.

For this study Heterogeneous or Maximum Variation Sampling was used. Teachers needed to be selected that were deviant from the norm by virtue of their atypical careerpath. The sample also needed to have a degree of balance between the range of possible classifications of cross-over. A purposive sample matrix was therefore devised to ensure 
representation from cross-over teachers in all of the school sectors that were considered to be large enough to be relevant in the context of the research (Table 4).

\section{Interviewee Selection}

A survey, which was completed by over 1,000 teachers $(5 \%$ of the NI teaching population), asked respondents to indicate whether or not they would be willing to contribute further to the research - 74 of those that volunteered were identified as having a community of origin (i.e. Protestant or Catholic) that was different to the community profile of the school in which they were currently working:

- Catholic teachers employed in Controlled schools or non-denominational grammar schools;

- Protestant teachers employed in Maintained schools or Catholic grammar schools; and,

- Teachers with either a Protestant or a Catholic identity employed in Integrated schools.

The purposive sample matrix was populated by randomly selecting three teachers from within each of the identified categories of cross-over. Three of these categories 'Protestant teaching in Maintained primary', 'Protestant teaching in Catholic grammar' and 'Catholic teaching in Controlled primary' - contained only three potential informants; the selection of these volunteers was consequently a zugzwang. In total 30 teacher interviews were undertaken between July and November 2017. Interviews lasted between 45 and 120 minutes. They were audio-recorded and fully transcribed. Each interviewee was assigned a pseudonym.

\section{Ethical Considerations}


Elliot (2005) identified two primary ethical considerations for any narrative inquiry: informed consent and confidentiality. Every respondent received and completed a consent form ahead of the interview commencing and were informed that if, on reflection, they decided that they wished to withdraw any or all of their interview, that this would only be possible prior to publication. Recording only started after the consent form had been signed.

Northern Ireland is a small place and those employed as teachers make up a small proportion of those living within it. Teachers who cross the community divide in education are something of an anomaly; school names and geographical location could, potentially, deprive an informant of their anonymity. These details were therefore removed from stored data.

\section{Verisimilitude}

Subjectivity is inherent within the social sciences and may, as Drapeau (2002) suggests, be one of its strengths. It is vital, however, to be able to assert that appropriate steps have been taken to ensure that the conclusions are robust, and that they have been drawn following a rigorous and transparent processes of analysing the available data. The interviewees responses were therefore scrutinised to ensure that they met the three dimensions of verisimilitude identified by Webster and Mertova (2007): firstly that the critical incidents cited resonated with the interviewer's own experience, secondly, that the reporting appeared truthful and thirdly, that the truthfulness of accounts could be discernible from their similarity with other events described by the interviewee.

\section{Findings}

Bourdieu proposed that by imposing meanings, ways of thinking and forms of expression 
schools are critical in the reproduction of cultural capital (Bourdieu and Passeron, 1990). In order to be effective carriers of culture, teachers need to be "deeply imbued with the practices and discourses" of their particular field of education and it is therefore necessary to impose exclusions and inclusions to ensure solidarity (Grenfell, 2014; 74).

Three themes were identified by the interviewees as potentially excluding teachers from moving between and across sectors in NI. Firstly, the impact of policy and, in particular, the roles played by the Certificate in Religious Education and the exception of teachers from Fair Employment legislation. Secondly, perceptions held about barriers that might or might not exist to employment outside of the teacher's own community, and thirdly practice in respect of recruitment and the prominence afforded to religion within the school (Figure 2).

\section{Policy: The Certificate, FETO Exception and RE}

Primary school teachers remain comprehensively separated in line with their community identity; this is most evident in the Maintained sector (Milliken et al, 2020). The occupational requirement that all teachers in these schools must be in possession of a Certificate in Religious Education (hereafter referred to as the Certificate) endorsed by the Catholic Trustees was seen by some interviewees as creating a barrier for Protestant teachers. This requirement, however, only applies to those who seek permanent posts. One interviewee had not completed the Certificate but had been able to gain employment as a teacher in a series of short-term posts in Maintained primary schools. When these posts were later advertised as permanent positions, she was unable to meet the qualification requirements. It was suggested by another teacher that the Certificate requirement may be concealing an ulterior motive. 
When you are in a Catholic school and you are advertising for a teacher you have to put that thing in about the Catholic certificate so it's highly unlikely you will get any non-Catholics applying for the job. There is a hidden agenda there.

All three Protestant interviewees who had been employed in Maintained primary schools expressed scepticism about the value of the Certificate. They suggested that, as it currently exists, the Certificate does not adequately prepare a non-Catholic teacher for supporting their pupils to follow the required religious practices and rituals. One teacher, who had completed the Certificate course by distance learning, was particularly scathing.

The Catholic Certificate of religion was absolutely, hopelessly, useless to teach $R E$ - it was completely useless.

The Certificate was seen by one respondent as a barrier without educational merit or practical justification.

The Certificate does not teach you anything that will help you teach in school -it will not give me more information to teach Catholic education than I already have. I know what I need to know - it's just a piece of paper that prevents me from teaching in that school... I can't see how having that certificate is going to make me a better teacher to those pupils.

Dunn and Gallagher (2002) proposed that teachers had been exempted from the protection afforded by Fair Employment legislation to appease Protestant teachers' concerns that whilst Catholic teachers (with the Certificate) could apply for a job on either side, Protestant teachers (without the Certificate) were unable to apply for posts in Maintained schools. There was evidence that some teachers may have been made aware of the teacher exception to FETO during their initial teacher education:

In teacher training you were told that schools had the right to employ their staff to reflect their student body. So, you were told that, if it's a 100\% Catholic school they have the right to - or they can fight to - have 100\% Catholic teachers. I know in those days it was simply - well you don't have much hope of getting in there. 
However, none of those interviewed could recall a case in which the FETO exception had been specifically called upon to justify an appointment. There was evidence that some schools (particularly in the grammar sector) may consider a candidate's community identity to be irrelevant for most posts.

I think the great thing about the principal is she picks best person for the job you know. The principal who hired me I think on the day she just went with the risk, "Let's go for it, it's a new thing!"

There is an intimation in this remark that, even where employment practices are more inclusive, the engaging of a community outsider may be judged as carrying with it an element of 'risk'.

\section{Perceptions}

The lack of movement between traditionally separated sectors was also explained by a series of perceptions - some of which had little grounding in fact. In the Republic of Ireland all primary school teachers are obliged to have the ability to not only teach the Irish language but also to be able provide instruction in Irish for all subjects. There is no such requirement for those applying to teach in Maintained schools in NI, but it appears that some Protestant teachers may be unaware of this and that this misunderstanding may be difficult to correct.

I heard a friend of mine saying there was no point in her applying to Catholic schools 'cos you need to have RE and you need to have Irish. I said, "You don't". She said, "You do!" And she had a whole big argument with me about it. But you don't! \{SIGHS\} You don't need it. I didn't know what she was talking about. I've taught in Catholic schools and I don't have Irish - you might need RE - I just don't know where she was getting that from.

As with the mistaken belief that evidence of competency in the Irish language is a prerequisite for employment in any post in the Catholic sector, so too may non-Catholic applicants felt that they could not apply for teaching post in any Catholic school without 
the Certificate. Although the Certificate is a stipulated occupational requirement for all permanent teaching posts in Maintained primary schools it is generally not required by post-primary teachers (although it has been requested for those teach religion or who have a specific pastoral role). This was illustrated by the Protestant vice-principal of a Catholic voluntary grammar school.

One of the big ones - people genuinely still believe that you need this RE certificate to teach in a Catholic school. And I say to people, "It's not included in the shortlisting criteria. It's not included in the interview. There's nothing different. We interview by the book. Set questions. Set criteria." There might be one [question] that mentions the Catholic ethos but all they are looking for is specific answers.

In the not-so-distant past, teachers would have been made aware of potential posts through newspaper advertisements. As with many aspects of life in NI, different newspapers are associated with one or other community. The choice of newspaper in which a particular post was advertised was likely to have been based on a predetermined concept of the community profile of prospective candidates. It would appear that some teachers may choose only to look for employment opportunities within familiar community parameters - that they are self-restricting when it comes to thinking about possible jobs on 'the other side'.

I was sitting in my husband's - now in-laws - we were going out and I remember going through the paper, the Irish News I think, and [my husband] saying, "That'd be really handy. Apply for that." And me going, "That's St [-]! How could I apply for that? A Catholic school." He went, "Why not?”... I would not have even thought about it - that fear of: you have to be a Catholic to teach in a Catholic school.

It was proposed that teachers often made the assumption that they would not be appointed to a school on the other side.

I think there are myths about the other schools: "Don't apply." "You won't get the job." "There's no point!" 
Thus, the community separation of teachers could take on the character of becoming a self-fulfilling prophecy - teachers choosing not to apply for posts on the other side because they presuppose that any such application would be unsuccessful - the veracity of such a supposition was thus effectively confirmed but never tested. In addition, even though Catholic teachers may have been able to apply to posts in Controlled primary schools, it was suggested they may be reluctant to do so and leave the familiarity of the Maintained school system.

Inotice that a lot of the people I did my PGCE with... stayed in the Catholic sector and I think a lot of the choices they made - the structures in Northern Ireland made that a whole lot easier for them - kept them hemmed in.

There was also an indication that some teachers aspired to returning to the school where they themselves had been educated.

I don't even think it's a matter of being stuck in the pattern of being in the same sector, I think a lot of people actually return to the same school, which is really strange. I think it's really insular.

\section{Practice}

Alongside the barriers of policy and perceptions, a number of tangible practice barriers were identified. The 1986 Education Order ensures that there are places guaranteed for nominees of three Protestant denominations (Church of Ireland, Presbyterian and Methodist) on the Boards of Governors of Controlled schools. There are currently approximately 1,900 of these transferor representatives serving as School Governors in NI.

Each of the main churches that were represented in the [Controlled primary] school had a minster on the Board of Governors... Ministers came in and took assemblies in rotation so that they would all be represented.

The governance of Maintained schools and Catholic grammars is overseen by the Catholic Schools' Trustees Service. Trustees are present on the Boards of Governors of 
all Catholic schools. More than half (16) of the teachers interviewed made comments in respect of the ways in which they felt that informal methods of recruitment and nepotism had impacted upon staff appointments. The role of the Boards of Governors in appointing staff was seen as having the potential to underpin this.

Some of the appointments in the past-prior to me being here - \{SIGHS\}I don't know how the people got the jobs. Somebody knew somebody whose grandfather was on the Board of Governors - all schools have teachers like that. But we are left with it.

There were indications that the potential for bias could take on a sectarian dimension given that Boards of Governors are likely to be comprised, predominantly, of members who share the same community identity.

A Catholic school will have nine Catholics on the Board of Governors - a Protestant school will have nine Prods [sic.] and, if there is any sectarianism, they aren't going to appoint somebody from the other side.

Family ties with the local Parish Priest were also seen as being potentially, particularly beneficial for applicants to posts in Catholic schools.

They are still trying to downsize the teaching force here, they won't give any fulltime jobs, very rarely unless you are the nephew of a Father such-and-such, which is another story... Frankly, I've taught on both sides that the nepotism's really, really $\{E M P H A S I S E D\}$ bad on the Maintained side of things.

Cultural and social separation in NI may be visible in the sports played and followed on either side of the community divide i.e. those sports with their origins in Britain and those associated with Irish identity. Sporting affiliations were identified as having potentially helped to open employment possibilities for teachers.

I know a lot of teachers in Tyrone who like to work in their local area to suit their Gaelic football interests. Some of the [county] GAA teams, they manage to get a cushy job in a local Catholic primary - it's a 'jobs for the boys'sort of thing.

Such favouritism was seen to have been a feature on both sides. 
My first job... was given to me in the understanding that I would play rugby for [the local club].

Family or close friendship connections with members of the school staff were also seen as possibly being valuable assets for those seeking employment in a school - particularly if that connection was with an individual in a senior management post.

So, there were two jobs came up and to be honest I had no notion of applying for them because I thought, "There's not a hope of me getting one of these jobs." But one of the guys - who was VP-said "Get you one of those forms filled in!"

In an era where year-on-year the number of newly qualified teachers entering the NI workforce far exceeds the number of permanent full-time teaching jobs available (Meredith, 2019), the informal recruitment of substitute or temporary teachers may further support separation - and build resentment.

I know a girl who works in St [-]'s she's never had to interview for a post-she walked into that job because it's the school she used to go to. She's been in her post four years and so she can apply for permanency without having ever to interview for a job.

As demonstrated in the example above, getting a foot in the door is seen as being crucial; once he or she is in post, the incumbent teacher may be hard to dislodge should the job eventually be made permanent.

They rang me - I was two weeks into this other post-they offered me a post for a year. The school I was in were very nice about it. So, I started there in the middle of October in 2012 - the job was then advertised as a permanent post and I got it.

Many of the interviewees commented on the different levels of religiosity that they encountered in each of the various sectors. Protestant teachers who had 'crossed-over' to work in the Maintained sector found that the way in which faith and prayer was woven into the daily life of these schools was unfamiliar. Religion and routine were identified 
as going hand-in-hand; twin mechanisms through which discipline could be maintained and an effective teaching environment could be established.

I [was] very surprised that every lesson starts with a prayer... But then I learned - actually very quickly (a few of the teachers told me) - that the reason they have to say the prayers is that it is a great way to get the discipline. So now we are sitting down and doing work. So, I started using the prayer then at the start of the lesson as a tool of being able to keep them under control.

Attention was drawn to the prominence of liturgy in Catholic schools, although some interviewees commented on a decline in religiosity in many homes and an increase in a less spiritual Catholicism. Parents were seen as being keen that their children should receive a traditional Catholic education yet showing less commitment when it came to regular attendance at mass.

There's a lot of them who would be not practicing. Where mummies and daddies have sent them just through tradition... In fact, there's always a lot of dental appointments, eye appointments, doctors' appointments whenever there are school masses.

There was a suggestion that this decline may serve to reinforce the Catholic church authorities' commitment to ensuring that faith is fostered through formal education.

Now that family faith is less prevalent, the Catholic church recognises that the way to promote the faith... is to do it through the schools.

One Protestant teacher spoke about her own deep, Christian faith; she found the centrality of religion in Catholic schools compatible with her own intense spirituality.

The faith thing is different - but that impresses me... For me being a Christian I'm going, "Wow! Imagine state schools being able to do that!"

By way of contrast, another Protestant teacher who was working in a Catholic grammar had over-estimated the religious presence that he would encounter on entering the sector.

My expectations were maybe like in the movies, you know, swinging incense burners, the sound of nuns in the background... [I told] one of the teachers [and he] said, "Oh my God! We must be slipping!" \{LAUGHTER\}. 
One Catholic primary school teacher who held a secular outlook on education found the relative absence of religion in Controlled schools to be a virtue.

In the Controlled sector... I was only spending one half-hour lesson a week teaching a bible story; we spoke about it first then did a worksheet and that was it done and dusted.

Whilst, for another Catholic teacher, the lack of familiar religious ritual in a non-Catholic school assembly was unusual and, to an extent, disconcerting.

Maybe you might have a morning prayer in assembly, "We'll bow our heads and say a prayer." And then nobody blesses themselves, and I found that strange... Their worship was more diluted, and I didn't really like that.

Integrated schools have their own perspective on religion. The teaching of religion in an integrated setting arguably necessitates more careful consideration of the differences between faiths than might be expected in a school with a specific denominational ethos or where the bulk of the pupils can be assumed to share a common religious identity. This was described by one teacher as being "a hidden kind of normal" that required teachers to embrace a broader understanding of religion than would be necessary for teachers in a different type of school.

Teaching RE in a Protestant school or a Catholic school... is just looking at 'you' whereas we [in an Integrated school] are dealing with 'everybody' $\{$ EMPHASISED $\}$.

\section{Discussion}

The evidence here indicates that the separation of teachers by community identity is predominantly the product of a gordian knot that binds together the Certificate, the FETO exception and the place afforded to denominational Christianity. These policy and practice factors would appear to have created, fed and sustained a perception that teaching jobs are simply not open to those from 'the other side'. The combined impact of teacher separation is most visible in respect of appointments to Controlled and Maintained 
primaries. The cultural capital of each respective school system is protected through formal policies and reproduced through practices and perceptions.

All schools in receipt of grant funding in NI are required (under the terms of the 1989 Education Reform Order) to provide pupils with both a daily act of collective worship and Religious Education in line with a syllabus drawn-up by the four largest Christian denominations (Catholicism, Presbyterianism, Anglicanism and Methodism). Primary school teachers are generally required to teach a single year group and to cover all curriculum areas with those pupils. It follows that in primary schools, most (and in many cases all) teachers will teach $\mathrm{RE}^{\mathrm{i}}$.

Catholic primary schools are instrumental in preparing pupils for the gateway sacraments of Reconciliation (in Year 3), First Holy Communion (in Year 4) and Confirmation (in Year 7). Integrated primary schools, which also prepare pupils for these sacraments, require only those teachers who are directly involved in the preparation process to be in possession of the Certificate.

In September 2019 Stranmillis University College (which has traditionally provided teachers for the Controlled sector) introduced an optional, in-house course leading to the awarding of the Certificate - the award is validated by St Mary's University College, the local Catholic teacher education institution. The Certificate had previously only been routinely available to those who attended St Mary's or who undertook the primary PGCE at Ulster University (where a Certificate, recognised by the Trustees, is awarded within a common Catholic/Protestant RE course).

Maintained primaries do not require temporary or supply teachers to be in possession of the Certificate - they have also relaxed the rule for those teachers who transfer from the 
Controlled to the Maintained sector to obviate redundancy; such teachers are allowed a three-year window within which to complete the certificate following transfer.

The criticism above of the Certificate's educational value, raises questions as to whether or not it can genuinely be accepted as a legitimate occupational requirement for all teaching posts in Maintained primary schools. As it is currently designed and delivered, it seems that the Certificate may be a filter that has had the effect of potentially excluding non-Catholics from employment in Maintained primary schools. The evidence presented here suggests that the Certificate may require revision if it is to adequately equip any teacher (Catholic or non-Catholic) with the knowledge and skills necessary to deliver a programme of education within the Catholic ethos.

This inequality of opportunity has been seen as being counterbalanced by the FETO exception, which could be used to restrict Catholic teachers from accessing posts in Controlled schools. This research found no evidence to indicate that the FETO exception is being extensively used in this way. The implications of possible nepotism in awarding teaching posts is also raised by this research. The removal of the FETO exception could allow for such allegations to be more rigorously tested in law.

Whether, if the FETO exception were to be removed and fair employment laws were to be fully applied to the appointment of teachers, the Certificate requirement could constitute discriminatory practice is a moot point, but the evidence presented here suggests that its continued presence, in its current form, contributes to maintaining the segregation by religion of primary school teachers.

It seems that action on four fronts could be required if opportunities are to be opened to enable teachers to access employment across all sectors. Firstly, the FETO exception 
would need to be removed. Secondly, the content, availability and place afforded to the Certificate by Maintained schools would need to be revised. Thirdly, the centrality of denominational Christian faith in all state funded schools would need to be reconsidered. Finally, nepotistic practices would need to be exposed and their legality challenged. With increased awareness of such changes the persistent prevalence of perceived barriers might reasonably be expected to dissipate.

\section{Conclusion}

The teacher who crosses between the community-defined systems of Northern Ireland remains something of a rarity - albeit that, in some sectors, the professional separation of teachers by community identity has been observed to be a less obvious feature of education than it had been in the past. The unique perspectives that have been provided here by teachers from one community who are teaching in schools serving another community raise challenging questions about recruitment and employment processes, perceived biases and assumptions imbedded in institutional practices. The evidence presented here suggests that if schools are to be able to select staff from the widest possible pool, teachers are to be able to access an increased range of employment opportunities and pupils are to benefit from being taught by someone with experiences beyond those of their own community background, then consideration needs to be given to addressing the policies, perceptions and practices that preserve professional separation.

Stimulating government action to enact the policy recommendations above is, perhaps, an over-ambitious aspiration for a paper of this nature. It is however hoped that this research may provide grist to the mill; a catalyst to stimulate change. It is also noted that this project may create further traction by revisiting the interview data to explore the 
extent to which cross-over teachers felt able to engage the 'otherness' of their identity in the classroom and thereby achieve professional agency.

Bourdieu considered that the reproduction of cultural capital through education was so effective that both sides (the dominant and the dominated) perceive the system as legitimate and therefore adhere unthinkingly to the rules (Grenfell, 2014). If Bourdieu's interpretations are valid then those teachers who cross the divide between schools in NI are a challenge the assumed integrity of the system. Their professional career choice is genuinely radical.

\section{References}

Akenson, D. (1973) Education and Enmity: the control of schooling in Northern Ireland Harper and Rowe, New York

Armstrong, D. (2009) Religious education and the law in Northern Ireland's Controlled Schools Irish Educational Studies, 28:3, 297-313.

Barnes, L.P. (2005) Religion, education and conflict in Northern Ireland. Journal of Beliefs \& Values, 26(2), 123-138.

Barry, J. (2017) From Power Sharing to Power Being Shared Out Green European Journal, $6^{\text {th }}$ July 2017 https://www.greeneuropeanjournal.eu/from-powersharing-to-power-being-shared-out/ (accessed 10 October 2019)

Bates, J. A. (2004) Use of narrative interviewing in everyday information behavior research Library \& Information Science Research 26, 15-28

Bourdieu, P. \& Passeron, J-C. (1990) Reproduction in education, society and culture ( $2^{\text {nd }}$ Edition) Sage, London

Braun, V. \& Clarke, V. (2006) Using thematic analysis in psychology. Qualitative Research in Psychology, 3, 77-101

Bryson, A. \& McConville, S. (2014) The Routledge guide to interviewing: oral history, social enquiry and investigation. Routledge, London

Charmaz, K. (2006) Constructing grounded theory: A practical guide through qualitative analysis. Thousand Oaks, CA: Sage. 
Dale, R. \& Robertson, S. (2009) Beyond Methodological 'Isms' in Comparative Education in an Era of Globalisation. In Handbook on Comparative Education, edited by A. Kazamias and R. Cowan, 1113-1128. Dordrecht: Springer.

Darby, J., Murray, D., Batts, D. Dunn, S., Farren, S. and Harris, J. (1977) Schools Together? Centre for the Study of Conflict, University of Ulster, Coleraine. https://cain.ulster.ac.uk/csc/reports/schools.htm (accessed 10 October 2019).

Department of Education NI (2013) Review of Employment Opportunities For Teaching Staff. Available at: https://www.educationni.gov.uk/sites/default/files/publications/de/Review-of-employmentopportunities-for-teaching-staff-Part-1.pdf (accessed 10 October 2019)

Department of Education NI (2015) Sharing Works: A policy for Shared Education. https://www.deni.gov.uk/sites/default/files/publications/de/shared-educationpolicy.pdf (accessed 10 October 2019)

Department of Education NI (2020) Annual Enrolments at schools 2019-20: Key Statistics DE Statistics and Research Team, Bangor

Drapeau, M. (2002). Subjectivity in research: Why not? But.... The Qualitative Report, 7(3), pp 1-15. Retrieved from http://nsuworks.nova.edu/tqr/vol7/iss3/3 (accessed 10 October 2019)

Dunn, S. \& Gallagher, T. (2003) The Teacher Exception Provision and Equality in Employment in Northern Ireland. Belfast, Equality Commission for NI.

Elbaz, F. (1990) Knowledge and discourse: the evolution of research on teacher thinking in Day, C., Pope, M. \& Denicolo, P. (eds.) Insights in teachers' thinking and practice. Falmer, London

Elliot, J. (2005) Using narrative in social research Sage Publications Ltd., London Equality Commission for Northern Ireland (2004) Investigation of the Teachers Exception under the Fair Employment and Treatment (NI) Order 1998. ECNI, Belfast https://www.equalityni.org/ECNI/media/ECNI/Publications/Delivering\%20Equa lity/TeacherExceptionfromFETOInvestigReport2004.pdf (accessed 10 October 2019). 
Etikan, I., Musa, S. \& Alkassim, R. (2016) Comparison of Convenience Sampling and Purposive Sampling. American Journal of Theoretical and Applied Statistics. Vol. 5, No. 1, pp. 1-4

Farren, S. (1989) Catholic-nationalist attitudes to education in Northern Ireland, 19211947, Irish Educational Studies, 8:1, 56-73

Furey, A., Donnelly, C., Hughes, J. \& Blaylock, D. (2017) Interpretations of national identity in post-conflict Northern Ireland: a comparison of different school settings, Research Papers in Education, 32 (2), 137-150

Gallagher, T. (2019) Education, Equality and the Economy. Belfast, Queens University https://www.qub.ac.uk/home/Filestore/Filetoupload,925382,en.pdf (accessed 1 October 2019

Grenfell, M. (2014) Pierre Bourdieu: Key Concepts (2 ${ }^{\text {nd }}$ Edition) Routledge, New York Hajisoteriou, C., Neophytou, L. \& Angelides, P. (2015) The perceptions of high-level officers in Cyprus about intercultural education and their underlying assumptions Curriculum Journal, 26 (1), pp. 115-136.

Hamber, B. (2007). Forgiveness and reconciliation: Paradise lost or pragmatism? Peace and Conflict, 13(1), 115-125.

Hughes, J. (2011) Are separate schools divisive? A case study from Northern Ireland, British Educational Research Journal, 37:5, 829-850, DOI: 10.1080/01411926.2010.506943

McCully, A. \& Emerson, L. (2014) Teaching controversial issues in Northern Ireland, in T. Misco \& J. de Groof (eds.), Cross-Cultural Case Studies in Controversial Issues: Pathways and Challenges in Democratic Citizenship Education. Tilberg, Legal Wolf Publishers.

Meredith, R. (2019) Northern Ireland training too many teachers BBC NI News $1^{\text {st }}$ August 2019 Available at: https://www.bbc.co.uk/news/uk-northern-ireland49177327 (accessed 4 October 2019)

Milliken, M., Bates, J. \& Smith, A. (2020) Education policies and teacher deployment in Northern Ireland: ethnic separation, cultural encapsulation and community cross-over, British Journal of Educational Studies, 68:2, 139-160, DOI: $\underline{10.1080 / 00071005.2019 .1666083}$ 
Mills, C. (2008) Reproduction and transformation of inequalities in schooling: the transformative potential of the theoretical constructs of Bourdieu. British Journal of Sociology of Education, 29 (1), 79-89.

Morse, J. (2000) Determining sample size. Qualitative Health Research, 10 (1), 3-5.

Nelson, J. (2010) Religious segregation and teacher education in Northern Ireland, Research Papers in Education, 25 (1), 1-20.

Novelli, M., Lopes Cardozo, M.T.A. \& Smith, A (2015) A Theoretical Framework for Analysing the Contribution of Education to Sustainable Peacebuilding: 4Rs in Conflict-Affected Contexts. University of Amsterdam, available online: http://learningforpeace.unicef.org/partners/research-consortium/researchoutputs/

Ritchie, J., Lewis, J. \& Elam, G. (2003). Designing and selecting samples. In Ritchie, J. and Lewis, J. (Eds.), Qualitative research practice. A guide for social science students and researchers (77-108) Thousand Oaks, CA: Sage.

Shukla, N., Wilson, E \& Boddy, J. (2014) Combining thematic and narrative analysis of qualitative interviews to understand children's spatialities in Andhra Pradesh, India. Novella: London

Smith, A., \& Hansson, U. (2015). A Review of Policy Areas Affecting Integration of the Education System in Northern Ireland. Ulster University, Coleraine

Sahlberg, P., Broadfoot, P., Coolahan, J., Furlong, F. \& Kirk, G. (2014) Aspiring to Excellence - Final Report of the International Review Panel on the Structure of Initial Teacher Education in Northern Ireland Department for Employment and Learning https://dera.ioe.ac.uk/20454/1/aspiring-to-excellence-review-panelfinal-report.pdf (accessed 10 October 2019)

Silverman, D. (2013). A very short, fairly interesting and reasonably cheap book about qualitative research. Sage

Squire, C., Davis, M., Esin, C., Andrews, M., Harrison, B., Hydén, L-C. \& Hydén, M. (2014) What is Narrative Research? Bloomsbury, London

Strauss, A. \& Corbin, J. (1998) Basics of Qualitative Research: Techniques and Procedures for Developing Grounded Theory $2^{\text {nd }}$ Ed. Sage, London Wardlow, M. (2013) Essentially Christian in Character: Ethos in Integrated Schools ( $\mathrm{PhD}$ Dissertation) 
https://www.academia.edu/5854050/Essentially_Christian_in_character_Ethos_i

n_Integrated_Schools (accessed 4 October 2019)

Webster, L. \& Mertova, P. (2007) Using Narrative Inquiry as a research method Routledge, London

Wyatt, T. (2019) Education: Schooling in the mix in Northern Ireland Church Times 20 Sept 2019 https://www.churchtimes.co.uk/articles/2019/20-

september/features/features/education-schooling-in-the-mix-in-northern-ireland (accessed 30 September 2019) 
Declaration of interest statement: This work was supported by the Department for Employment and Learning, Northern Ireland through a funded PhD studentship.

Acknowledgements: The authors would like to express their gratitude to everyone who contributed to this research project. Particular thanks are due to Dr Alan McCully for his valuable feedback during the preparation of this paper 


\begin{tabular}{|l|r|r|r|}
\hline & Maintained Primary & Maintained Post-primary & Catholic Voluntary Grammar \\
\hline Darby et al, 1977 & $<1 \%$ & $2 \%$ & \\
\hline ECNI, 2004 & $2 \%$ & $2 \%$ & $1 \%$ \\
\hline
\end{tabular}

Table 1: Protestant teachers employed in Maintained schools and Catholic voluntary grammars 


\begin{tabular}{|l|r|r|r|}
\hline & Controlled Primary & Controlled Post-primary & $\begin{array}{c}\text { Non-Denominational Voluntary } \\
\text { Grammar }\end{array}$ \\
\hline Darby et al, 1977 & $<1 \%$ & $2 \%$ & $1 \%$ \\
\hline ECNI, 2004 & $5 \%$ & $5 \%$ & \\
\hline
\end{tabular}

Table 2: Catholic teachers employed in Controlled schools and non-denominational grammars 


\begin{tabular}{|c|c|c|c|c|}
\hline \multirow[t]{2}{*}{ School Management Sector } & \multicolumn{4}{|c|}{ \% Teachers Employed by Primary School Sector Attended } \\
\hline & Controlled & Maintained & Integrated & Other \\
\hline Maintained Primary & $2 \%$ & $93 \%$ & $1 \%$ & $4 \%$ \\
\hline Maintained Post-primary & $8 \%$ & $83 \%$ & $1 \%$ & $8 \%$ \\
\hline Catholic Voluntary Grammar & $17 \%$ & $72 \%$ & $3 \%$ & $8 \%$ \\
\hline Controlled Primary & $85 \%$ & $7 \%$ & $2 \%$ & $6 \%$ \\
\hline Controlled Post-primary & $73 \%$ & $17 \%$ & $0 \%$ & $10 \%$ \\
\hline Non-Denominational Voluntary Grammar & $65 \%$ & $23 \%$ & $1 \%$ & $11 \%$ \\
\hline Integrated Primary & $46 \%$ & $36 \%$ & $10 \%$ & $8 \%$ \\
\hline Integrated Post-primary & $43 \%$ & $38 \%$ & $7 \%$ & $11 \%$ \\
\hline
\end{tabular}

Table 3. Deployment of Teachers by Primary School Attended 


\begin{tabular}{|c|c|c|c|c|}
\hline PRIMARY & Teaching in Maintained Primary & \multicolumn{2}{|c|}{ Teaching in Controlled Primary } & Teaching in Integrated Primary \\
\hline Catholic teacher & $\mathrm{N} / \mathrm{A}$ & \multicolumn{2}{|c|}{3} & 3 \\
\hline Protestant teacher & 3 & \multicolumn{2}{|c|}{ N/A } & 3 \\
\hline SECONDARY & $\begin{array}{c}\text { Teaching in Maintained Post- } \\
\text { primary }\end{array}$ & \multicolumn{2}{|c|}{$\begin{array}{c}\text { Teaching in Controlled Post- } \\
\text { primary }\end{array}$} & $\begin{array}{c}\text { Teaching in Integrated Post- } \\
\text { primary }\end{array}$ \\
\hline Catholic teacher & N/A & \multicolumn{2}{|c|}{3} & 3 \\
\hline Protestant teacher & 3 & \multicolumn{2}{|c|}{$\mathrm{N} / \mathrm{A}$} & 3 \\
\hline GRAMMAR & \multicolumn{2}{|c|}{ Teaching in Catholic Grammar } & \multicolumn{2}{|c|}{ Teaching in Non-denominational Grammar } \\
\hline Catholic teacher & \multicolumn{2}{|l|}{ N/A } & \multicolumn{2}{|r|}{3} \\
\hline Protestant teacher & \multicolumn{2}{|l|}{3} & \multicolumn{2}{|r|}{$\mathrm{N} / \mathrm{A}$} \\
\hline
\end{tabular}

Table 4: Purposive Sample Matrix 
Figure 1. \% of Mainstream Pupils in NI attending Integrated Schools (Primary and Post-primary) since the Good Friday Agreement

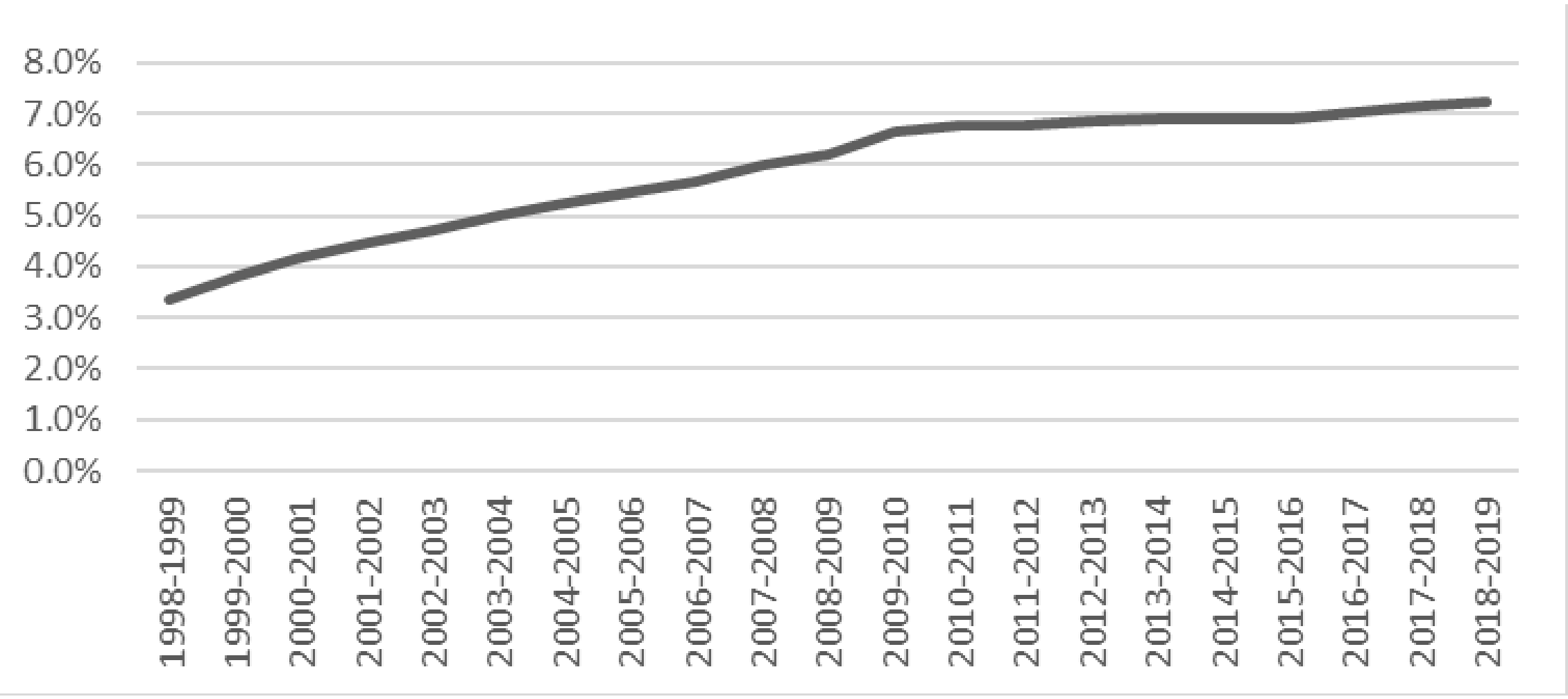


Figure 2. Factors that moderate teachers' movement between and across sectors

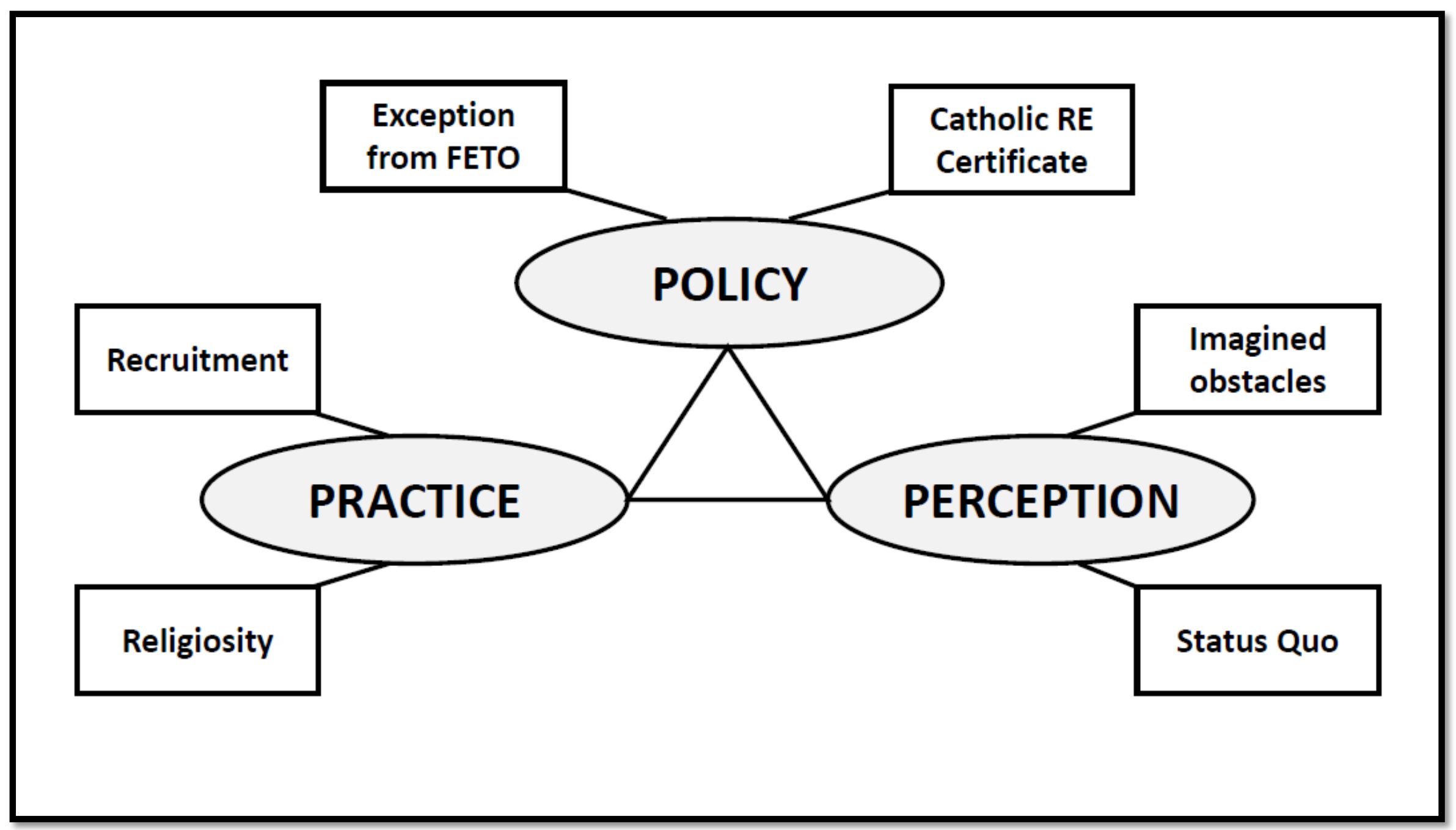


${ }^{\mathrm{i}}$ Teachers, in Controlled schools who on conscience grounds feel that they cannot teach religious education, can request to be exempted from teaching the subject. There is no equivalent explicit statement on teachers' right of conscience for those employed in Maintained schools.

${ }^{\text {ii }}$ ECNI research provided a breakdown against only three categories: Controlled, Maintained and Voluntary Grammar. Primary and post-primary figures have therefore been duplicated. The ECNI research had an additional identity categorisation 'undertermined'. 